\title{
Front Matter: Volume 8855
}

, "Front Matter: Volume 8855," Proc. SPIE 8855, Optics and Photonics for Information Processing VII, (14 October 2013); doi: 10.1117/12.2045985

SPIE Event: SPIE Optical Engineering + Applications, 2013, San Diego, California, SPIE. United States 


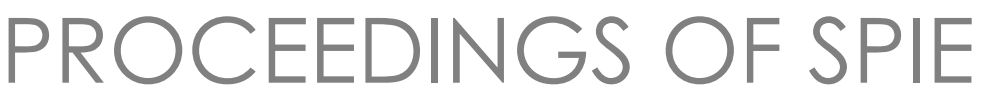

\section{Optics and Photonics for Information Processing VII}

Khan M. Iftekharuddin

Abdul A. S. Awwal

Andrés Márquez

Editors

28-29 August 2013

San Diego, California, United States

Sponsored and Published by

SPIE 
The papers included in this volume were part of the technical conference cited on the cover and title page. Papers were selected and subject to review by the editors and conference program committee. Some conference presentations may not be available for publication. The papers published in these proceedings reflect the work and thoughts of the authors and are published herein as submitted. The publisher is not responsible for the validity of the information or for any outcomes resulting from reliance thereon.

Please use the following format to cite material from this book:

Author(s), "Title of Paper," in Optics and Photonics for Information Processing VII, edited by Khan M. Iftekharuddin, Abdul A. S. Awwal, Andrés Márquez, Proceedings of SPIE Vol. 8855 (SPIE, Bellingham, WA, 2013) Article CID Number.

ISSN: 0277-786X

ISBN: 9780819497055

Published by

SPIE

P.O. Box 10, Bellingham, Washington 98227-0010 USA

Telephone +1 3606763290 (Pacific Time) · Fax +1 3606471445

SPIE.org

Copyright @ 2013, Society of Photo-Optical Instrumentation Engineers.

Copying of material in this book for internal or personal use, or for the internal or personal use of specific clients, beyond the fair use provisions granted by the U.S. Copyright Law is authorized by SPIE subject to payment of copying fees. The Transactional Reporting Service base fee for this volume is $\$ 18.00$ per article (or portion thereof), which should be paid directly to the Copyright Clearance Center (CCC), 222 Rosewood Drive, Danvers, MA 01923. Payment may also be made electronically through CCC Online at copyright.com. Other copying for republication, resale, advertising or promotion, or any form of systematic or multiple reproduction of any material in this book is prohibited except with permission in writing from the publisher. The CCC fee code is 0277-786X/13/\$18.00.

Printed in the United States of America.

Publication of record for individual papers is online in the SPIE Digital Library.

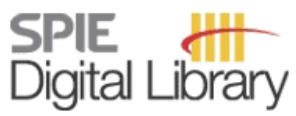

SPIEDigitalLibrary.org

Paper Numbering: Proceedings of SPIE follow an e-First publication model, with papers published first online and then in print and on CD-ROM. Papers are published as they are submitted and meet publication criteria. A unique, consistent, permanent citation identifier (CID) number is assigned to each article at the time of the first publication. Utilization of CIDs allows articles to be fully citable as soon as they are published online, and connects the same identifier to all online, print, and electronic versions of the publication. SPIE uses a six-digit CID article numbering system in which:

- The first four digits correspond to the SPIE volume number.

- The last two digits indicate publication order within the volume using a Base 36 numbering

system employing both numerals and letters. These two-number sets start with 00, 01, 02, 03, 04, $05,06,07,08,09,0 A, 0 B \ldots 0 Z$, followed by 10-1Z, 20-2Z, etc.

The CID Number appears on each page of the manuscript. The complete citation is used on the first page, and an abbreviated version on subsequent pages. Numbers in the index correspond to the last two digits of the six-digit CID Number. 


\section{Contents}

vii Conference Committee
ix Introduction

\section{SESSION 1 OPTICAL SYSTEMS I}

885502 Production, detection, and manipulation of vortex beams and radially polarized beams (Invited Paper) [8855-1]

I. Moreno, Univ. Miguel Hernández de Elche (Spain); J. A. Davis, D. M. Cottrell, San Diego

State Univ. (United States)

885503 Optical asymmetric cryptosystem using polarized light [8855-2]

S. K. Rajput, N. K. Nishchal, Indian Institute of Technology Patna (India)

885504 Study of the modulation capabilities of parallel aligned liquid crystal on silicon displays [8855-3]

A. Márquez, F. J. Martínez, S. Gallego, M. Ortuño, J. Francés, A. Beléndez, I. Pascual, Univ. de Alicante (Spain)

885505 Cardiac rate detection method based on the beam splitter prism [8855-4]

L. Yang, X. Liu, M. Liu, Y. Zhao, L. Dong, R. Zhao, X. Jin, Beijing Institute of Technology

(China); J. Zhao, 152 Central Hospital of the People's Liberation Army (China)

\section{SESSION 2 OPTICAL SYSTEMS II}

885506 Digital holographic tomography using a light back propagation method and its application for refractive index measurement [8855-5]

T. Nomura, T. Kitazawa, Wakayama Univ. (Japan)

885507 Designing the acousto-optical cell for optical spectrometer incorporated into the Guillermo Haro Astrophysical Observatory [8855-6]

A. S. Shcherbakov, A. O. Arellanes Bernabe, V. Chavushyan, Instituto Nacional de Astrofísica, Óptica y Electrónica (Mexico)

885508 Fast hologram pattern generation by wave field translation [8855-7]

S. Lee, H. C. Wey, D. K. Nam, D. S. Park, Samsung Electronics, Co., Ltd. (Korea, Republic of)

$88550 \mathrm{~A}$ Storage density estimation for the phase-encoding and shift multiplexing holographic optical correlator [8855-9]

T. Zheng, L. Cao, Q. He, G. Jin, Tsinghua Univ. (China) 
8855 OB Implementation of a photonic antenna in optical OFDM link [8855-10]

S. Kenshil, G. Rashwan, M. Matin, Univ. of Denver (United States)

8855 OC Optical signal impairment study of cascaded optical filters in 40 Gbps DQPSK and 100 Gbps PM-DQPSK systems [8855-11]

X. Chen, P. R. Horche, A. M. Minguez, Univ. Politécnica de Madrid (Spain)

8855 OD PAPR mitigation algorithms for OFDM WiMAX link [8855-12]

G. Rashwan, S. Kenshil, M. Matin, Univ. of Denver (United States)

8855 OE Electro-optic logic circuits based on silicon microring switches [8855-13]

L. Yang, L. Zhang, Y. Tian, Institute of Semiconductors (China)

\section{SESSION $4 \quad$ IMAGE PROCESSING I}

8855 OF On-chip optical matrix-vector multiplier (Invited Paper) [8855-14]

L. Yang, L. Zhang, R. Ji, Institute of Semiconductors (China)

8855 OG Highway traffic segmentation using super-resolution and Gaussian mixture model [8855-15] A. H. Yousef, J. Flora, K. Iftekharuddin, Old Dominion Univ. (United States)

$8855 \mathrm{OH} \quad$ Object tracking under nonuniform illumination with adaptive correlation filtering [8855-16] K. Picos, V. H. Díaz-Ramírez, Ctr. de Investigación y Desarrollo de Tecnología Digital (Mexico); V. Kober, Ctr. de Investigación Científica y de Educación Superior de Ensenada (Mexico)

$8855 \mathrm{Ol} \quad$ Using orthogonal self-loop coded aperture in a pushbroom computational spectral imager [8855-18]

Y. Liu, B. Xiangli, Q. Lv, H. Min, Z. Jinsong, Academy of Opto-Electronics (China)

\section{SESSION $5 \quad$ IMAGE PROCESSING II}

8855 0J A recognition method in holographic data storage system by using structural similarity [8855-19]

Y.-T. Chen, National Central Univ. (Taiwan, China); M. Ou-Yang, National Chiao Tung Univ. (Taiwan, China); C.-C. Lee, National Central Univ. (Taiwan, China)

8855 OK Robustness of double random phase encoding spread-space spread-spectrum image watermarking technique [8855-20]

S. Liu, Univ. College Dublin (Ireland); B. M. Hennelly, National Univ. of Ireland, Maynooth (Ireland); J. T. Sheridan, Univ. College Dublin (Ireland)

$8855 \mathrm{OL}$ Monte Carlo simulation of neutron noise effects on beam position determination at the National Ignition Facility [8855-21]

A. S. Awwal, R. R. Leach Jr., P. Datte, A. Manuel, Lawrence Livermore National Lab. (United States) 
8855 OM Data mining with unsupervised clustering using photonic micro-ring resonators [8855-22] A. D. McAulay, Lehigh Univ. (United States)

$8855 \mathrm{ON}$ The laser range profile and range imaging of a coarse cone [8855-23]

Y. Li, Z. Wu, L. Bai, H. Li, Y. Cao, Xidian Univ. (China)

$885500 \mathrm{XOR} / \mathrm{XNOR}$ directed logic circuit based on coupled-resonator-induced transparency [8855-25]

Y. Tian, Lanzhou Univ. (China) and Institute of Semiconductors (China); L. Zhang, L. Yang, Institute of Semiconductors (China)

POSTER SESSION

8855 OP Integration of coherent optical OFDM with WDM [8855-27]

K. Alatawi, F. Almasoudi, M. A. Matin, Univ. of Denver (United States)

$88550 Q$ Theoretical and experimental examination of PQ-PMMA photopolymer material [8855-28]

Y. Qi, H. Li, Univ. College Dublin (Ireland); E. Tolstik, Friedrich-Schiller-Univ. Jena (Germany);

J. Guo, The Univ. of Electro-Communications (Japan); M. R. Gleeson, Tyndall National Institute (Ireland); V. Matusevich, R. Kowarschik, Friedrich-Schiller-Univ. Jena (Germany); J. T. Sheridan, Univ. College Dublin (Ireland)

8855 OR Spatial frequency response of AA/PVA photopolymer material containing four different photosensitizers [8855-29]

Y. Qi, H. Li, Univ. College Dublin (Ireland); J. Guo, The Univ. of Electro-Communications (Japan); M. R. Gleeson, Tyndall National Institute (Ireland); J. T. Sheridan, Univ. College Dublin (Ireland)

8855 OS Anaglyph stereo images generated from object topography obtained through fringe projection [8855-30]

Y. Y. López Dóminguez, A. Martínez García, J. A. Rayas Álvarez, Ctr. de Investigaciones en

Óptica A.C. (Mexico); K. Genovese, Univ. degli Studi della Basilicata (Italy)

8855 OT Enhancement of nonlinear phase shift for format conversion in silicon waveguides [8855-32] P. Zhou, S. Gao, X. Li, K. Hu, Zhejiang Univ. (China)

8855 OU Known plain-text attack on asymmetric cryptosystem [8855-33]

S. K. Rajput, N. K. Nishchal, Indian Institute of Technology Patna (India)

$8855 \mathrm{OV}$ Analysis of the fabrication of diffractive optical elements in photopolymers [8855-34] S. Gallego, A. Márquez, R. Fernández, Á. Piera, F. J. Martínez, M. Ortuño, J. Francés, A. Beléndez, I. Pascual, Univ. de Alicante (Spain)

8855 OW Spatial attributes of the diffraction field [8855-35] J. Munoz-Lopez, G. Martínez Niconoff, G. Diaz-Gonzalez, J. Silva Barranco, Instituto Nacional de Astrofísica, Óptica y Electrónica (Mexico); P. Martínez Vara, Benemérita Univ. Autónoma de Puebla (Mexico) 
8855 OY Research progress of depth detection in vision measurement: a novel project of bifocal imaging system for 3D measurement [8855-26]

A. Li, Y. Ding, W. Wang, Tongji Univ. (China); Y. Zhu, Zhejiang Univ. of Science and Technology (China); Z. Li, Tongji Univ. (China)

Author Index 


\title{
Conference Committee
}

\author{
Program Track Chair
}

Khan M. Iftekharuddin, Old Dominion University (United States)

\section{Conference Chairs}

Khan M. Iftekharuddin, Old Dominion University (United States)

Abdul A. S. Awwal, Lawrence Livermore National Laboratory (United States)

Andrés Márquez, Universidad de Alicante (Spain)

\section{Conference Program Committee}

Ghaleb M. Abdulla, Lawrence Livermore National Laboratory (United States)

Henri H. Arsenault, University Laval (Canada)

George Barbastathis, Massachusetts Institute of Technology (United States)

Juan Campos, Universidad Autònoma de Barcelona (Spain)

David Casasent, Carnegie Mellon University (United States)

Pietro Ferraro, Istituto Nazionale di Ottica (Italy)

Laurence G. Hassebrook, University of Kentucky (United States)

Kazuyoshi Itoh, Osaka University (Japan)

Mohammad Ataul Karim, Old Dominion University (United States)

Byoungho Lee, Seoul National University (Korea, Republic of)

Abhijit Mahalanobis, Lockheed Martin Missiles and Fire Control (United States)

Mohammad A. Matin, University of Denver (United States)

Osamu Matoba, Kobe University (Japan)

Alastair D. McAulay, Lehigh University (United States)

Nasser M. Nasrabadi, U.S. Army Research Laboratory (United States)

Thomas J. Naughton, National University of Ireland, Maynooth (Ireland)

Mark Allen Neifeld, The University of Arizona (United States)

Takanori Nomura, Wakayama University (Japan)

Ting-Chung Poon, Virginia Polytechnic Institute and State University (United States)

Philippe Réfrégier, Institut Fresnel (France)

Joseph Rosen, Ben-Gurion University of the Negev (Israel)

John T. Sheridan, University College Dublin (Ireland)

Enrique Tajahuerce-Romera, University Jaume I (Spain)

Jun Tanida, Osaka University (Japan)

Cardinal Warde, Massachusetts Institute of Technology (United States) 
Eriko Watanabe, The University of Electro-Communications (Japan)

Frank Wyrowski, Friedrich-Schiller-Universität Jena (Germany)

Toyohiko Yatagai, Utsunomiya University (Japan)

Francis T. S. Yu, The Pennsylvania State University (United States)

María J. Yzuel, Universidad Autònoma de Barcelona (Spain)

\section{Session Chairs}

P1 Signal, Image, and Data Processing Plenary Session

Khan M. Iftekharuddin, Old Dominion University (United States)

1 Optical Systems I

Khan M. Iftekharuddin, Old Dominion University (United States)

2 Optical Systems II

Takanori Nomura, Wakayama University (Japan)

3 Hybrid Systems

Mohammad A. Matin, University of Denver (United States)

4 Image Processing I

Andrés Márquez, Universidad de Alicante (Spain)

5 Image Processing II

Abdul A. S. Awwal, Lawrence Livermore National Laboratory

(United States) 


\title{
Introduction
}

This year in San Diego, California, we held the seventh conference of Optics and Photonics for Information Processing. Like last year the conference attracted very interesting papers in a wide number of areas such as hybrid opto-electronic systems, pattern recognition, optical holographic systems, optical systems, 3-D displays, hyperspectral image processing, optical communications and sensors. This conference track preceded by an invited Signal and Image Processing trackwide plenary talk by Dr. Stephen Aylward of Kitware. He presented a lively hour long discussion on advantages, history, current status, and future direction of open source software in industry and academia. The conference of Optics and Photonics for Information Processing VII was formally opened by an enlightening invited presentation by Dr. Moreno from Universidad Miguel Hernández, Elche, Spain, who showed clever ways to produce and manipulate vortex and radially polarized beams and their enormous potential in optical free space communication. The conference had papers in optical systems, optical communication, and digital optical image processing. The papers presented in the conference contained good balance between theoretical, numerical and application oriented works. This conference also provides a training ground for graduate students, this year was no exception. We had a number of Masters and $\mathrm{PhD}$ student presentations. These presentations, as a whole, have shown to the audience the latest developments occurring in a wide range of the modern information processing areas.

We thank all who helped making this an exciting conference, especially the authors, audience and SPIE staff. Our special thanks go to the audience for their active participation by the way of asking engaging questions after most of the presentations. For next year, we look forward to seeing you in this conference, and hope that you will help us make the eighth edition an appealing place for discussion of the latest advances in the field.

\author{
Khan M. Iftekharuddin \\ Abdul Ahad S. Awwal \\ Andrés Márquez Ruiz
}

